\section{Blood group substances as differentiation markers in human dento-gingival epithelium}

\author{
Steffensen, B., Lopatin, D. E., Caffesse, R. G., Hanks, C. T. Blood group substances \\ as differentiation markers in human dento-gingival epithelium. Journal of Perio- \\ dontal Research 1987; 22: 451-455.
}

\begin{abstract}
The level of cellular differentiation of human oral, sulcular, and junctional epithelium was compared by immunohistochemical analysis of cell membrane-associated blood group-specific carbohydrates. Identification of the blood group A-specific carbohydrate and its two immediate precursor substances, type 2 chain $\mathrm{H}$ and $\mathrm{N}$-acetyllactosamine, was accomplished by an indirect immunofluorescence technique. Murine monoclonal antibodies reacting specifically with the antigenic determinants of the blood group substances were used as markers. The blood group A substance, indicating the highest level of cellular differentiation, was demonstrated on the cells in the upper layers of the oral epithelium. In the sulcular epithelium, the A substance was present on a few cells only, while type 2 chain $\mathrm{H}$ was observed frequently. This indicates an intermediate differentiation level of sulcular epithelium. The type 2 chain $\mathrm{H}$ precursor, $\mathrm{N}$-acetyllactosamine, the indicator of the lowest level of cell differentiation among the tested substances, was the only blood group substance detected on the junctional epithelial cells and on the basal cells of the sulcular and oral epithelium. Based upon previous studies of cell renewal and differentiation in oral epithelium, the present results indicate that the variations in distribution of the different blood group substances correspond with the regional rates of cell division and the levels of cellular differentiation. The findings also suggest that the cells in the junctional epithelium differentiate to a level similar to that of basal cells in the oral epithelium.
\end{abstract}

B. Steffensen*, D. E. Lopatin, R. G. Caffesse and C. T. Hanks Departments of Periodontics, Oral Biology, and Oral Pathology, School of Dentistry, University of Michigan, Ann Arbor, Michigan, U.S.A.

Accepted for publication April 23, 1987

\section{Introduction}

The epithelium of the human dento-gingival region has been divided into oral, sulcular, and junctional epithelium (1, 2 ). The differences in structural and functional characteristics of these epithelia, such as tissue permeability (3), variation in ultrastructure (4), rate of cellular division (5), and degree of keratinization (6), have been attributed to embryogenic development, tissue interaction and the special environment in the dento-gingival area $(7,8)$. The junctional epithelium retains specific qualities which are clearly distinct from the sulcular and oral gingival epithelium. However, after surgical removal, a new junctional epithelium can regenerate from the oral epithelium $(2,9-12)$. The nature of the processes leading to

*Present address: Department of Periodontics, University of Texas Health Science Center, San Antonio, Texas, U.S.A. reestablishment of structure and function of the junctional epithelium is not yet fully understood (13).

Blood group-specific carbohydrate substances have been detected on epithelial cell membranes as well as on erythrocytes (14). It has been demonstrated, biochemically, that the specificity of the blood group substances is determined by variations in the structure of the terminal sugar residues on the carbohydrate chains $(15,16)$. Analysis of epithelial blood group substances has been shown to be useful in studies of cell differentiation of normal oral epithelium $(17,18)$ and in conditions of premalignancy, malignancy, and wound healing $(19,20)$. Current data indicate that the synthesis and elongation of the blood group-specific carbohydrates are correlated to the differentiation and maturity of epithelial cells $(17,18,20)$. Thus, with increasing differentiation, the epithelial cells express more developed carbohydrates. Very few similar data are available on the level of cellular differentiation of the different epithelial components of the dento-gingival area in humans (21). Results from studies in mice indicate, however, that the junctional epithelium is less differentiated than sulcular or oral epithelium (8, 22).

The aim of the present investigation was to compare the level of cellular differentiation between human oral, sulcular, and junctional epithelium by immunohistochemical identification of three well-defined epithelial blood group substances.

\section{Material and methods Tissue samples}

Twenty-one biopsies of marginal gingiva were obtained from 14 patients during periodontal surgery (16 specimens) or in combination with tooth extraction (5 specimens). Blood typing showed that 11 patients had blood type 


\begin{tabular}{|c|c|c|}
\hline Antigen & $\begin{array}{l}\text { Carbohydrate } \\
\text { structure }\end{array}$ & $\begin{array}{l}\text { Mouse } \\
\text { monoclonal } \\
\text { antibodies }\end{array}$ \\
\hline$\stackrel{\text { A }}{\text { determinant }}$ & $\begin{array}{ll}\text { GalNAcal } & 1--3 \\
\text { L-Fucal } & \text { or } \\
2 & \end{array}$ & $\begin{array}{l}\text { "AH16" } \\
\text { Type } 1 \text { or } 2 \\
\text { chain }\end{array}$ \\
\hline $\begin{array}{c}\mathrm{H} \\
\text { determinant }\end{array}$ & L-Fuca1--2Gal $\beta 1--4$ GlcNAc1--R & $\begin{array}{l}\text { "BE2" } \\
\text { Type } 2 \text { chain- } \\
\text { specific }\end{array}$ \\
\hline $\mathrm{N}$-acetyllactosamine & Gal $\beta 1--4 G l c N A c--R$ & $\begin{array}{l}\text { "1B2" } \\
\text { Type } 2 \text { chain- } \\
\text { specific }\end{array}$ \\
\hline
\end{tabular}

Gal = Galactose.

$\mathrm{Gl}=$ Glucose .

Fuc $=$ Fucose .

$\mathrm{Ac}=$ Acetyl.

GlcNAc $=\mathrm{N}$-acetyl-D-glucosamine.

Fig. l. The chemical composition of the carbohydrate chains specific for the blood group substances $\mathrm{A}$, type 2 chain $\mathrm{H}$, and $\mathrm{N}$-acetyllactosamine.

0 and 3 patients had blood type A. Biopsies from patients with these blood types were selected because previous studies have demonstrated the blood group substances type 2 chain $\mathrm{H}$ and $\mathrm{N}$-acetyllactosamine in epithelium from individuals with blood type 0 and, in addition, the blood group $A$ substance in persons with blood type A (20).

The patients were appraised of the study and informed consents were obtained consistent with the policies of The University of Michigan and the NIH.

\section{Tissue processing}

Sixteen specimens were fixed in a $4 \%$ neutral buffered formaldehyde solution,

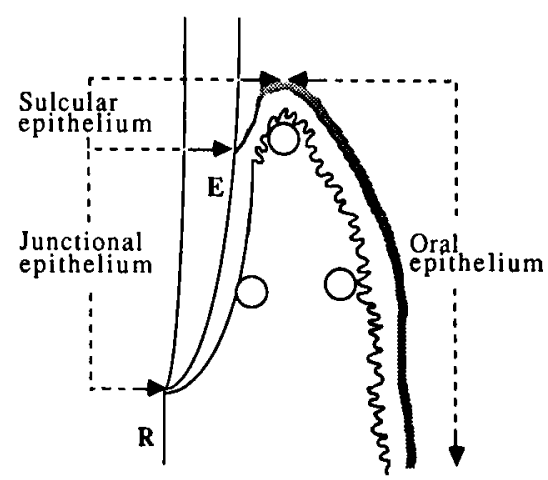

Fig. 2. Schematic drawing of a gingival tissue section illustrating the oral, sulcular, and junctional epithelium. The circles represent the areas in the subepithelial connective tissue where the inflammatory cell infiltrate was evaluated. and 5 specimens were fixed in Bouin's fixative (23). Following fixation, the specimens, which included tooth substance, were placed in a buffered 0.5 mol/l EDTA solution ( $\mathrm{pH} 7.1$ ) for decalcification of the hard tissues. All specimens were embedded in paraffin and cut at 4-5 microns-thick sections. The sections were deparaffinized with xylene and hydrated in graded ethanol and phosphate buffered saline at $\mathrm{pH} 7.4$ (PBS) before the staining procedure.

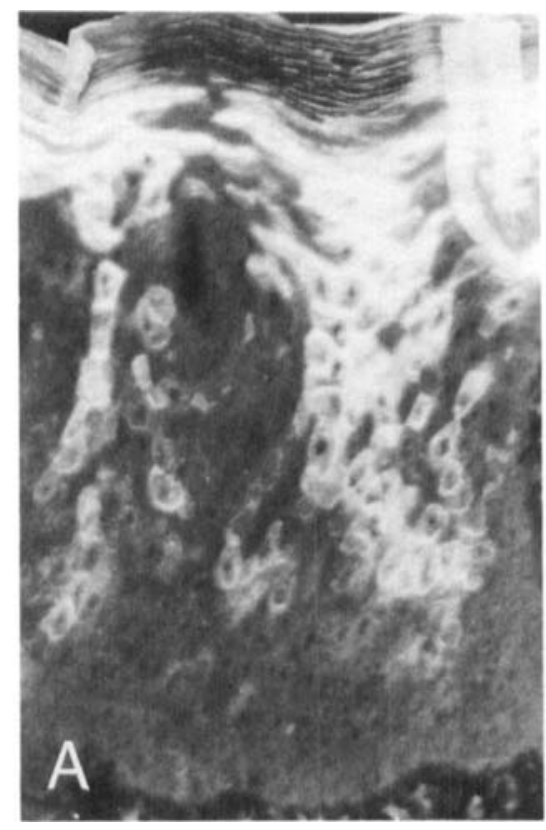

Fig. 3. Oral epithelium from a patient having blood type A ( $\times 250)$. A: Immunofluorescence staining of the blood group A substance using murine monoclonal antibodies. B: Hematoxylineosin staining of the section shown in A.

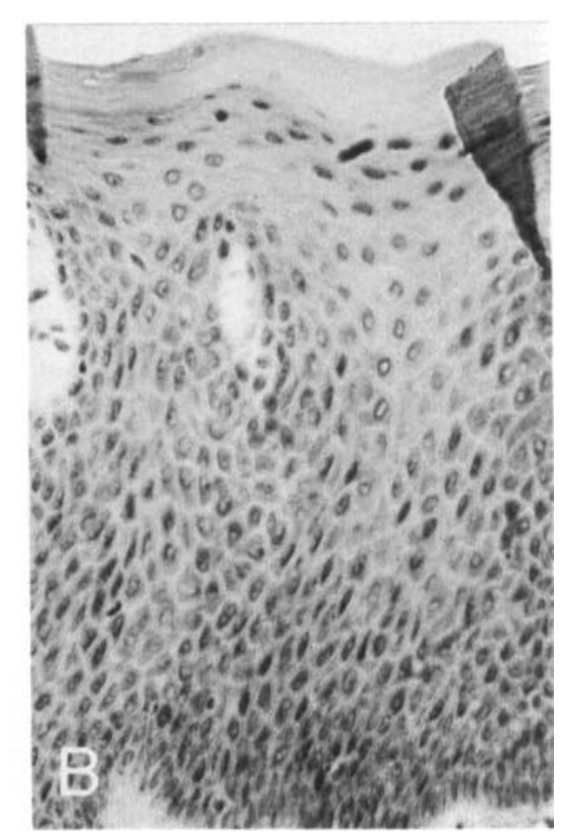

Similar procedures for tissue processing have previously been shown to enable clear detection of epithelial blood group substances $(17,18)$.

\section{Antibodies and conjugates}

The epithelial blood group substances were identified by an indirect immunofluorescent staining technique. Murine monoclonal antibodies reacting with carbohydrates specific for the complete blood group A substance (AH16) (24) and the immediate precursor substances, type 2 chain H (BE2) (25) or $\mathrm{N}$-acetyllactosamine (1B2) (25) were applied to the sections as the primary antibodies. The chemical composition of the carbohydrate determinants for these blood group substances is shown in Fig. 1. (The murine monoclonal antibodies were obtained as a gift from Dr. S.I. Hakomori, Fred Hutchinson Cancer Research Center, Seattle, WA). The secondary antibodies were goat anti-mouse immunoglobulins $(\mathrm{IgA}+\mathrm{IgG}+\mathrm{IgM}$, heavy and light chain-specific) conjugated with fluorescein isothiocyanate (FITC) for immunofluorescence visualization (Cappel Scientific Div., Malvern, PA).

\section{Staining procedure}

The tissue sections were incubated in a humidity chamber with the primary 

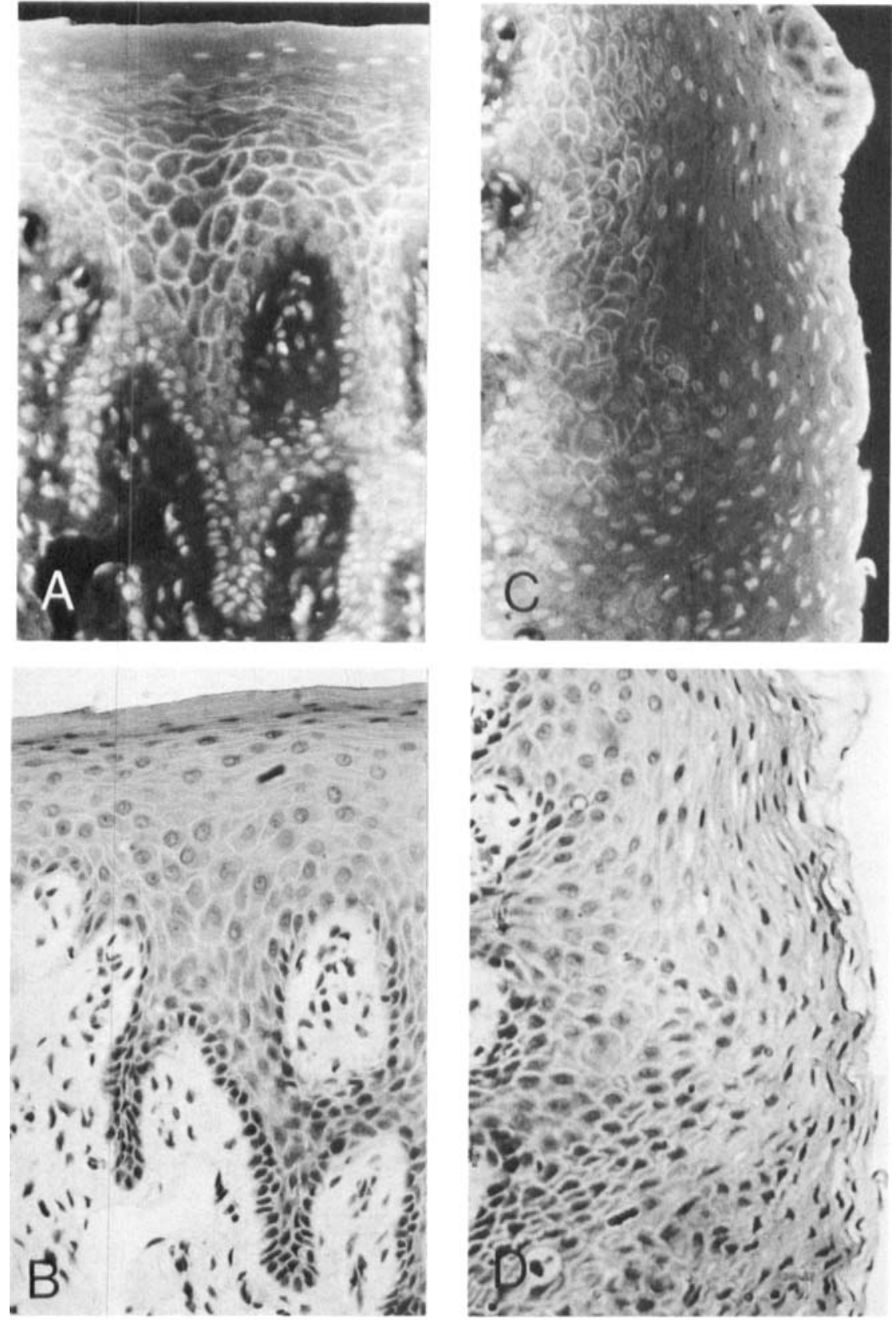

Fig. 4. Gingival epithelium from a patient having blood type $\mathrm{O}(\times 250)$. Immunofluorescent staining of the blood group substance type 2 chain $\mathrm{H}$ using murine monoclonal antibodies in (A) oral epithelium and $(C)$ sulcular epithelium. B and C: Hematoxylin-eosin staining of the sections shown in $\mathrm{A}$ and $\mathrm{C}$.

murine monoclonal antibodies at a dilution of $1: 5$ for $24 \mathrm{~h}$ at $4^{\circ} \mathrm{C}$. After three rinses with PBS, each for $5 \mathrm{~min}$, a 1:10 dilution of the secondary goat antimouse antibodies was added to the sections and they were incubated for $1 \mathrm{~h}$ at room temperature. Following repeated PBS rinses and slight air-drying, the sections were mounted in a glycerol/PBSbased mounting medium containing para-phenylenediamine to reduce fading (26). nous cells was determined in each area. After examination and photography in the IF microscope, the sections were restained with hematoxylin-eosin (HE), permitting comparison of the IF staining reaction with the normal histology.

\section{Degree of inflammation}

The degree of inflammation was determined from the HE-stained sections. In each section, the total number of inflammatory cells was counted (field size $=1.3 \mathrm{~mm}^{2}$ at $400 \times$ ) in the connective tissue located immediately beneath a) the oral epithelium, b) the sulcular epithelium, corresponding to the region where keratinization disappeared, and c) the junctional epithelium at the midpoint between the most coronal collagen fiber attachment and the most apical part of the sulcular epithelium. These cell counts were related to the IF staining patterns (Fig. 2).

\section{Control reactions}

Control reactions included a) staining with FITC-conjugated goat anti-mouse antibodies alone, b) substitution of PBS in place of the murine monoclonal antibodies, and c) application of the hybridoma cell culture media in place of the cultured hybridoma supernatant fluid containing antibody.

\section{Results}

\section{Blood group A substance}

The blood group A substance was found on single cells or groups of cells in the upper spinous cell layers in the oral epithelium (Fig. 3). Only single scattered cells in the most superficial cell layers of the sulcular epithelium showed presence of the A substance. No substance $A$ was detected in the junctional epithelium.

\section{Type 2 chain $\mathbf{H}$ substance}

In the ortho-keratinized oral epithelium, the type 2 chain $H$ substance was demonstrated on cells in all spinous cell layers (Fig. 4A) and on parabasal cells over the connective tissue papillae. This substance was also present in the paraor non-keratinized sulcular epithelium but was, in this region, limited to the parabasal and deeper spinous cells (Fig. 4C). A clear borderline of the staining reaction for the type 2 chain $\mathrm{H}$ substance, corresponding to the morpho- 


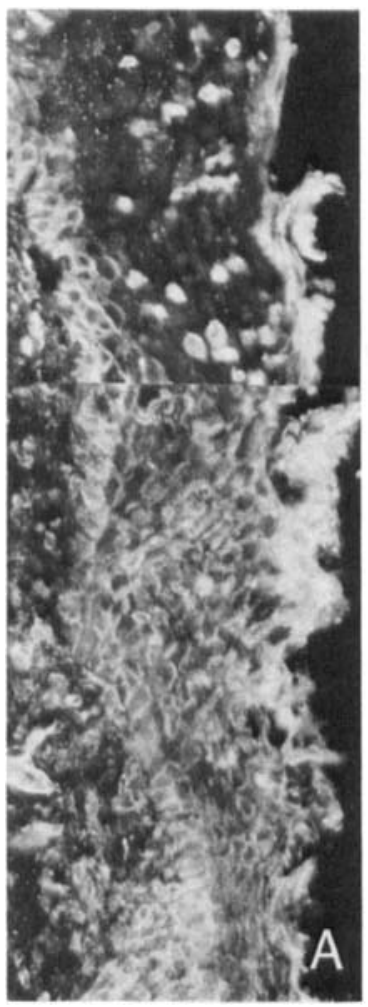

Fig. S. Junctional epithelium from a patient having blood type $O(\times 250)$. A: Immunofluorescence staining of blood group substance $\mathrm{N}$-acetyllactosamine using murine monoclonal antibodies. B: Hematoxylin-eosin staining of the section shown in A.

logical border between the sulcular and junctional epithelial cells, could be observed. In the junctional epithelium, only single separate cells carried the type 2 chain $\mathrm{H}$ substance.

\section{N-acetyllactosamine}

$N$-acetyllactosamine was observed on cell in the whole width of the junctional epithelium, especially in the more apical areas (Fig. 5). Like the staining reaction for the antibodies to type 2 chain $\mathrm{H}$ substance, the demarcation of the staining reaction for $\mathrm{N}$-acetyllactosamine corresponded to the morphological delineation between junctional and sulcular epithelium. The $\mathrm{N}$-acetyllactosamine was also detected on the basal cells of the oral and sulcular epithelium, and on the parabasal cells of the oral epithelial ridges.

\section{Degree of Inflammation}

The degree of inflammation in the specimens ranged from a total of 32 to 385 inflammatory cells per field $\left(1.3 \mathrm{~mm}^{2}\right)$. No relationship between the inflamma-

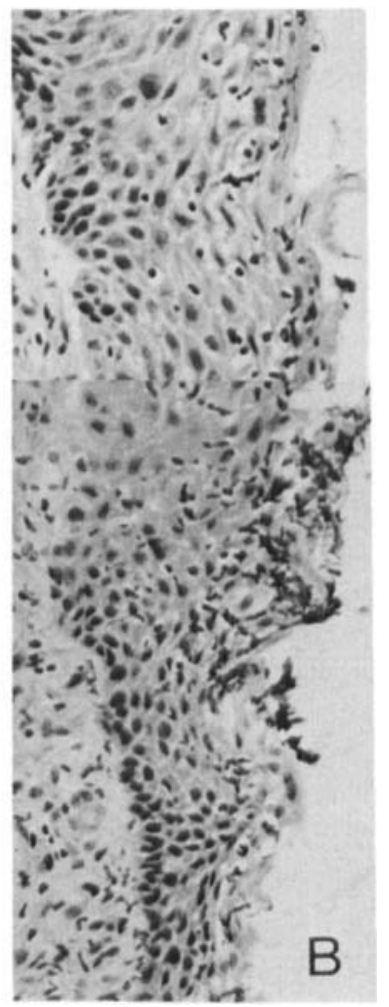

hydrates $(17,20,24,25)$. Previously, Dabelsteen and coworkers $(17,20)$ have used similar methods on oral epithelium and have demonstrated that the incomplete carbohydrates are present on the least mature cells, and that the complete carbohydrates are found on more mature and more highly differentiated cells. In agreement with their findings, the results from this investigation showed that the most complete blood group substance, the A substance, was located in the upper layers of the oral epithelium and the precursor substances, type 2 chain $\mathrm{H}$ and $\mathrm{N}$-acetyllactosamine, were present in the deeper cell layers. Thus, the location of the different carbohydrates can be interpreted as a reflection of the maturity and differentiation of the epithelial cells.

The distribution of the blood group substances in the different regions of the dento-gingival epithelium seemed to be related to the rate of cell proliferation. Thus, the least developed carbohydrate, $\mathrm{N}$-acetyllactosamine, was widespread in the junctional epithelium which has a very high rate of cell division $(5,9,27$, 28 ). The rates of cell division in the regions where the type 2 chain $\mathrm{H}$ and the $\mathrm{A}$ antigens were detected (i.e. the sulcular and oral epithelium), are known to be lower than in the junctional epithelium $(5,9,27,28)$. In other words, the results clearly indicated a relationship between the level of cellular differentiation and the regional rates of cell division.

In studies of epithelium from other parts of the oral cavity, the location of blood group substances has been related to the type and degree of keratinization (18). This is in agreement with the findings in the present study. The type 2 chain $\mathrm{H}$ substance was found on cells at a higher cell layer in ortho-keratinized oral epithelium compared to the non- or para-keratinized sulcular epithelium (Fig. 4 A-D). Previous observations have demonstrated an association between the degree of keratinization and the rate of cellular division of the sulcular epithelium $(6,29)$. The present findings may, however, also indicate that the type of keratinization is associated not only with the rate of cellular division but also with the level of cellular differentiation as represented by blood group substances.

It has been reported that an inflammatory infiltrate in the subepithelial connective tissue influences the mitotic rate of the overlying epithelium (30). 
It was, therefore, anticipated that less mature epithelial cells might be detected in areas with a high inflammatory cell count than in areas with a low degree of inflammation. However, comparisons of the distribution of blood group substances between different tissue sections in the present study did not reveal such alterations of cellular maturation due to subepithelial connective tissue inflammation. This may, in the oral epithelium, be the result of an overall low degree of inflammation. As even the least inflamed sections of the sulcular and, in particular, the junctional epithelium demonstrated blood group substances representative for cells with a low level of differentiation, a further decline may not have been detectable.

Detection and analysis of cell membrane-associated carbohydrates, i.e. blood group substances, has already for some time been used for investigations of cell behavior and differentiation in conditions of premalignancy and malignancy in the human oral epithelium (19, 20 ). The results from this study indicate that the method might be a valuable tool for understanding early healing and cell differentiation in the dento-gingival area.

\section{Acknowledgements}

The authors gratefully acknowledge Dr. Leif Hellden for critical review of the manuscript. This investigation was supported by USPHS grant DE-02731 from the National Institute of Dental Research, Bethesda, and the LeGro Fund from the School of Dentistry, Ann Arbor, Michigan.

\section{References}

1. Engler WO, Ramfjord SP, Hinniker JJ. Development of epithelial attachment and gingival sulcus in Rhesus monkeys. $J$ Periodontol 1965; 36: 45.

2. Schroeder HE, Listgarten MA. Fine structure of the developing epithelial attachment of human teeth, monograph. Basel: S. Karger, 1977.

3. Osborn JW, Ten Cate AR. The dentogingival junction. In: Advanced Dental Histology: 4th ed. Bristol: Wright PSG 1983: 142.
4. Schroeder HE, Munzel-Pedrazzoli S. Morphometric analysis comparing junctional and oral epithelium of normal human gingiv. Helv Odont Acta 1970; 14 : 53.

5. Hill MW. Cell renewal in oral epithelia. In: Meyers J, Squier CA, Gerson SJ, eds. The structure and function of oral mucosa. Oxford: Pergamon Press, 1984: 53.

6. Caffesse RG, Kornman KS, Nasjleti CE. The effect of intensive antibacterial therapy on the sulcular environment in monkeys. Part I. Inflammation, mitotic activity and keratinization of the sulcular epithelium. J Periodontol 1980; 51: 155.

7. Mackenzie IC, Binnie WH. Recent advances in oral mucosal research. $J$ Oral Path 1983; 12: 389.

8. Mackenzie IC. The role of epithelialmesenchymal interactions in epithelial migration and differentiation. $J$ Period Res 1984; 19: 656.

9. Engler WO, Ramfjord SP, Hinniker JJ. Healing following simple gingivectomy. A tritiated thymidine radiographic study. I. Epithelialization. J Periodontol 1966; 37: 298.

10. Listgarten MA. Electron microscopic study of the junction between surgically denuded root surfaces and regenerated periodontal tissues. J Period Res 1972; 7: 68 .

11. Listgarten MA. Ultrastructure of the dento-gingival junction after gingivectomy. J Period Res 1972; 7: 151.

12. Braga AM, Squier CA. Ultrastructure of the regenerating junctional epithelium of the monkey. J Periodontol 1980; 51: 386.

13. Mackenzie IC, Hill MW. Maintenance of regionally specific patterns of cell proliferation and differentiation in transplanted skin and oral mucosa. Cell Tissue Res 1981; 219: 597.

14. Szulman AE. The histological distribution of blood group substances $A$ and $B$ in man. $J$ Exp Med 1960; 111: 785.

15. Watkins WM. The glycosyltransferase products of the A, B, H, and Le genes and their relationship to the structure of the blood group antigens. In: 5th International Convocation on Immunology. Buffalo, N. Y., 1977: 267.

16. Hakomori S-I. Blood group A, B, H and Ii antigens of human erythrocytes: Chemistry, polymorphism, and their developmental change. Semin Hematol 1981; 18: 39.

17. Dabelsteen E, Vedtofte P, Hakomori SI, et al. Carbohydrate chains specific for blood group antigens in differentiation of human oral epithelium. $J$ Invest Dermatol 1982; 79: 3 .
18. Vedtofte P, Dabelsteen E, Hakomori S-I, et al. Regional variations of cell surface carbohydrates in human oral stratified epithelium. Differentiation 1984; 25 : 221.

19. Hakomori S-I. Glycosphingolipids in cellular interaction: Differentiation and oncogenesis. Annu Rev Biochem 1981; 50: 733 .

20. Dabelsteen E. Receptors on the keratinocyte surface. In: Meyers J, Squier CA, Gerson SJ, eds. The Structure and Function of Oral Mucosa. Oxford: Pergamon Press, 1984: 83.

21. Brandtzaeg $P$. Localization of bloodgroup substances A and B in alcoholfixed human gingivae by indirect immunofluorescence technique. Acta Odont Scand 1965; 23: 335.

22. Mackenzie IC, Rittman BR, Vercelotti P. Phenotypic markers of murine junctional epithelium. J Dent Res 1986; 65 (spec iss): Abs. 68

23. Sheehan DC, Hrapchak BB. Theory and Practice of Histotechnology. 2nd ed. St. Louis: C. V. Mosby Co., 1980.

24. Abe K, Levery SB, Hakomori S-I. The antibody specific to type 1 chain blood group A determinant. J Immunol 1984; 132: 1951 .

25. Young WW, Portoukalian J, Hakomori S-I. Two monoclonal anticarbohydrate antibodies directed to glycosphingolipids with a lacto-N-glycosyl Type II chain. $J$ Biol Chem 1981; 256: 10967

26. Johnson GD, Davidson RS, McNamee $\mathrm{KC}$, et al. Fading of immunofluorescence during microscopy: A study of the phenomenon and its remedy. $J$ Immunol Methods 1982; 55: 231.

27. McHugh WD, Zander WA. Cell division in the periodontium of developing and erupted teeth. Dent Pract 1965; 15: 451.

28. Skougard M. Turnover of the gingival epithelium in marmosets. Acta Path Scand 1965; 23: 623.

29. Caffesse RG, Karring T, Nasjleti CE. Keratinizing potential of sulcular epithelium. J Periodontol 1977; 48: 140.

30. Hopps RM, Johnson NW. Relationship between histological degree of inflammation and epithelial proliferation in Macaque gingiva. J Periodont Res 1974; 9: 273.

Address:

Dr. Bjorn Steffensen,

Department of Periodontics, University of Texas Health Science Center,

7703 Floyd Curl Drive

San Antonio. Texas 78284-7894,

U.S.A. 